\title{
Hodosi Anett
}

\section{A bizalom mint költségcsökkentő tényező}

\begin{abstract}
Jelen tanulmányban az egyik legtöbbet kutatott informális intézmény, a bizalom direkt és indirekt költségcsökkentő hatását vizsgáljuk. A bizalom mikroszintü bevezetését makroszintű megközelítés követi, mely a bizalom tranzakciós költségeken keresztüli közvetlen és a jogrendszeren keresztül történö közvetett, tovagyürüző költségcsökkentő hatására kiván rávilágítani. Utóbbi részeként 25 európai uniós ország empirikus vizsgálata során a bizalom és az adminisztratív teher okozta költségek - mint a jogrendszer által generált költségek - közötti összefüggéseket elemezzük. A közgazdasági irodalom igazolja egyrészt, hogy a bizalom csökkenti a tranzakciós költségeket, másrészt, hogy a jogrendszer hatékonysága hozzájárul a tranzakciós költségek csökkenéséhez. Feltevésünk szerint a bizalom növekedése javítja a jogrendszer hatékonyságát, és ezen keresztül is csökkenti a tranzakciós költségeket.
\end{abstract}

Journal of Economic Literature (JEL) kód: D02, E02

Kulcsszavak: bizalom, tranzakciós költségek, jogrendszer és bizalom

Gyakori jelenség, hogy az érzelmeket mint irracionális, a jól elrendezett élet akadályozó faktoraiként kezelik (Elster 1997), azonban az egyének egymáshoz füződő viszonyának a közgazdasági elemzésbe történő bevonásával tulajdonképpen a korábbi hagyományokhoz térünk vissza. Adam Smith, John Stuart Mill vagy Vilfredo Pareto is azt tartotta, hogy az emberek összetett lények (Hámori 2003), akiket az érzelmeik éppúgy befolyásolnak döntéshozás közben, mint az ésszerüség.

Rendkívül fontos érzelmi alapú tényezőnek, egyben informális intézménynek tekinthetjük a bizalmat, amelyet Tarnai (2003) alapján négyféleképpen definiálhatunk:

- egyfajta egyéni elvárás, várakozás, az események kívánatos kimenetelébe vetett hit, mely nagymértékben tartalmaz emocionális elemeket,

- interperszonális kapcsolat, melyben az egyén sebezhetővé válik, mivel a másik fél tetteit nem tudja kontrollálni,

- társas struktúrák által alkotott jelenség, melynek célja a megbízható viselkedés biztosítása,

- a gazdasági tranzakciós költségeket befolyásoló tényező.

Számos irodalom igazolja, hogy a bizalom csökkenti a tranzakciós költségeket, illetve az is alátámasztott, a jogrendszer hatékonysága is hozzájárul a tranzakciós költségek csökkenéséhez. Jelen tanulmányban feltesszük, hogy a bizalom növekedése javítja a jogrendszer hatékonyságát, és ezen mechanizmuson keresztül is csökkenti a tranzakciós 
költségeket. Az elemzés során a bizalom fontosságának mikroszintü megalapozását követően, annak makroszintü hatására fókuszálunk, melynek részeként a hipotézisben meghatározott negatív irányú kapcsolatot vizsgáljuk empirikusan.

\section{A bizalom szerepe mikroszinten}

A bizalom kialakulásában több tényező játszik szerepet. Négy jelentősebbet emelhetünk ki: (1) a személyes fogékonyság, (2) a másik fél kontrollálhatósága, (3) a jó hírnév alapján történő kategorizálás, amikor egy harmadik fél véleményére alapozva ítélik bizalomra méltónak vagy sem a személyt, illetve (4) a már meglévő sztereotípiák hatása. Mindezek javítják a partner pozitív megítélését, optimista érzéseket váltanak ki, hozzájárulva a bizalom kialakulásához és fenntartásához (Mayer-Davis 1999).

Fukuyama (1995a) a bizalmat a társadalmi tőke kiaknázásához elengedhetetlenül fontos tényezőként tartja számon. A társadalmi tőke ugyanis értelmezhető az embercsoportok azon képességeként, hogy közös célok érdekében együttesen, szervezetekben tevékenykednek, melynek hatékonyságát jelentősen befolyásolja a bizalom szintje, így például a vállalatok egymás közötti kapcsolatainak eredményessége szempontjából jelentősnek tekinthető. A vállalatok esetében a bizalom kialakulásában és fennmaradásában négy tényező játszik szerepet, a partner cég tulajdonságai, az adott kapcsolat története, az alkalmazottak attitűdjei és a velük való személyes kapcsolatok. Az üzleti partnerbe vetett bizalom kialakulása három módon segíthető elő (Woodruff 2005): (1) a bíróság által kikényszeríthető formális szerződések, (2) a múltbeli tapasztalatok, illetve (3) a partner harmadik féllel való kapcsolatából eredő hírneve1. Mindezek pozitívan befolyásolják a bizalom szintjét, hiszen mindhárom esetben megjelenik a külső kikényszeríthetőség vagy az annak szükségtelenségébe vetett hit.

A másik személy észlelt tulajdonságai és a kialakított egyéni benyomások fontos szerepet játszanak, ezért a partnerek nagy erőfeszítést tesznek, hogy pozitív imázst alakítsanak ki önmagukról. Kísérleti eredmények azt mutatják, hogy a felek közti együttmüködés akkor a leggyakoribb, ha fenyegetésre egyik félnek sincs lehetősége. Ritkább, ha bármelyik fél egyoldalúan fenyegetheti partnerét, illetve legritkábban akkor fordul elö, ha a potenciális fenyegetés kétoldalú (Kovács 2003).

Maga a döntéshozatal egy összetett folyamat végeredményeként jellemezhetö, mely során kiemelkedő szerephez jut az információk helytállóságának bizonytalansága, a másik fél megbízhatósága és az ebben rejlő kockázat, illetve a közös célok és értékek megléte. A döntési szituációt ezek mellett nagyban befolyásolja még, hogy mennyire állnak rendelkezésre más alternatívák, milyen értékeket tartunk fontosnak, és azokat hogyan rangsoroljuk. Mindezeket mérlegelve, a folyamat végén a döntéshozó saját ítéletén múlik, hogy együttműködésre érdemesnek ítéli-e az adott helyzetet vagy sem (Al-Mutairi et al. 2008).

Ha a partnerek bíznak egymásban, sokkal inkább együttműködő magatartást folytatnak, nem "taktikáznak” és kevésbé gyanakvóak (Kovács 2003). A bizalomnak tehát közvetlenül érzékelhető gazdasági haszna van. Mindennek persze megvan a kockázata is, ezért fontos kiemelni, hogy a bizalom megjelenése a gazdaságban semmiképpen sem feltétel nélküli. Az 
esetek többségében rövidtávon kifizetödő csalni, ám ebben az esetben biztosak lehetünk benne, hogy a viszonzás is hasonló lesz, rövidre zárva ezzel egy esetlegesen jövedelmező kapcsolatot.

Megfelelő feltételek mellett a hosszú távú, együttműködésen alapuló kapcsolatok versenyelőnyt jelentenek (Wahl - Nowak 1999)2, melyek egyik legfontosabb jellemzője, hogy a felek nem azonnal akarják hasznukat maximalizálni, hanem egy későbbi, az önzőn versengő magatartás esetében realizált jövedelemnél nagyobb megtérülés reményében rugalmasabban viszonyulnak egymáshoz. Mindezért a kapcsolat elején a partnerek többletköltségeket vállalnak, sőt engedményeket is tesznek, ám a kölcsönös függőség, illetve a bizalom mértékétől függően a kooperatív kapcsolat kiépítése igen jövedelmező alternatíva mindkét fél számára.

Jó példát szolgáltat minderre a távol-keleti családi vállalatok kiterjedt szervezete, melyek világpiaci sikerességük nagy részét az egymásba vetett bizalomnak köszönhetik (Artner 1995). Ezen hálózatokon belül a feltételeket nem foglalják írásos szerződésbe, illetve az ellentételezés mértéke nem feltétlenül reális. Ezt a rendszert a bizalom és az etikus viselkedés íratlan kódexe tartja össze. Sok esetben a segítséget nem is az adott recipiens viszonozza, hanem a tágabb közösség valamely tagja. Továbbá az ilyen reciprok kapcsolatokon nyugvó, bonyolult rendszerekben, a közönséges árucserével ellentétben, mindig vannak „nettó adósok” és „nettó hitelezők” (Hámori 2003:63). Így a személyek és szervezetek kölcsönös függésében fontos, hogy a felek számíthassanak partnereikre, amikor a helyzet úgy kívánja. A bizalom végül is egyfajta beruházás, amely szilárdabb alapra helyezi, ezáltal segíti elő a kereskedelmet. A gyémántkereskedelem komplex szabályrendszere mintegy ezeréves múlttal rendelkezik, ahol igen gyakran egy kézfogás és a héber-jiddis kifejezés: Mazel és Brucha (szerencse és áldás) által válik érvényessé egy - akár milliós nagyságrendü szerződés (Brenner 1994).

Bizalom nélkül mindez kizárólag erőteljes kontrollal, szerződésekkel, a döntéshozatal és a struktúrák merev szabályozásával lenne lehetséges, amelyek viszont rendkívül költségigényesek, és így nem hatékonyak (Tarnai 2003).

\section{A bizalom mint makroszintü költségcsökkentő tényező}

A továbbiakban a bizalom direkt és indirekt költségcsökkentő hatását vizsgáljuk makroszinten, melyhez Tarnai (2003) alapján a bizalmat tranzakciós költséget befolyásoló tényezőként definiáljuk. A bizalom közvetlen, költségeket befolyásoló hatásának értelmezéséhez a tranzakciós költségek elméletéből indulunk ki.

A tranzakciós költség ${ }^{3}$ a csere során felmerülő költségek összességeként határozható meg (Dahlman 1979). Mivel a csere folyamatát három fö részre bonthatjuk: (1) a megfelelő cserepartner megkeresése és kiválasztása, (2) az alku feltételeinek kidolgozása és a szerződés megkötése, illetve (3) az alku betartásának utólagos nyomon követése, az esetleges megszegés büntetése. Ezek alapján a tranzakciós költséget is három fö részre oszthatjuk, keresési, alku- és érvényesítési költségre (Cooter-Ulen 2005:97).

\footnotetext{
2 Lásd bővebben: Hodosi (2008)

3 Lásd bővebben: Coase (2004).
} 
A csere egyes fázisai nyilvánvalóan befolyásolják a tranzakciós költség nagyságát, melyet csökkenthet (1) a tiszta, világos jogrend, (2) a kevésszámú résztvevő, (3) ha a felek ismerősek, vagy (4) mértéktartóan, méltányosan viselkednek, illetve (5) az azonnali csere, (6) a bizonytalanság hiánya vagy (7) az alacsony ellenőrzési és büntetési költségek megléte (Cooter-Ulen 2005:105).

Látható, hogy a piaci folyamatok müködtetése költséggel jár. Ha a termelés minden fázisa a piacon menne végbe formális és informális intézményi keret nélkül, a magas tranzakciós költségeknek köszönhetően a végtermék ára is rendkívül magas lenne. Termelési megközelítésben a költségek csökkentésének egyik módja a szükséges folyamatok belsővé tétele, mely esetben „a vállalat a termelés piaci szervezésének alternatíváját jelenti. A vállalaton belül az együttműködő termelési tényezők közötti egyéni alkut kiküszöbölik, és a piaci tranzakciókat adminisztratív döntésekkel helyettesítik" (Coase 2004:164). Az ezzel járó költséget nevezzük adminisztratív költségnek. Természetesen ennek során is fontos szerepet játszik a bizalom, annak kiépítése és fenntartása, melyet nagymértékben befolyásol a vállalat struktúrája, irányítási formája és a személyzet összetétele. Mindezek azonban már vállalaton belül kerülnek meghatározásra, a kontroll pedig a bizonytalanság és az abból fakadó pluszköltségek csökkentését jelenti.

Coase (2004) értelmezésében az önálló szervezetek sok esetben költséghatékonyabb alternatívát jelentenek a piachoz képest, mivel egyfajta megoldásként szolgálnak a piaci folyamatokból fakadó - a bonyolult és jövőbeni események prognosztizálhatóságának hiánya miatt - nem elégséges szerződésekre, illetve a hosszú táv kiszámíthatatlanságára. A bizalmi alapú kapcsolatok meghatározhatók a piaci szervezés és a vállalat alternatívájaként, így a coase-i megközelítést továbbgondolva ezen interakciók egyértelmủen tranzakciós és adminisztratív költséget csökkentő hatással bírnak. A bizalom „csökkenti a tranzakciós ráfordításokat, és javítja az együttmüködést azon gazdasági szereplök között, akik különben a kölcsönösen előnyös cserét túl költségesnek vagy kockázatosnak ítélik" (Raiser et al. 2005:73). Az együttműködés is költséggel jár, és természetesen a bizalom kialakulásához szükséges információk összegyüjtése növeli az adminisztratív költségeket, de összességében pozitív hozadékkal jár.

Kereslet-kínálati megközelítésben mindezt szélesebb körre is kiterjeszthetjük. Thomas C. Schelling $(1958,1963)$ a gazdasági interakciók felosztását játékelméleti szemszögből vizsgálja, mely során a klasszikus zéró és nem-zéró összegű játékok helyett tiszta konfliktust (pure conflict), tiszta közös érdeket (pure common-interest) és vegyes, vagy más néven alkujátékot (mixed or bargaining game) különböztet meg. Az első esetben a játékosok kimenetelre vonatkozó preferenciái között negatív korreláció figyelhető meg, míg a második esetre pozitív kapcsolat a jellemző. A tiszta konfliktus jelenti a kizárólagos versenyhelyzetet, amelyet ellentétes célok összességeként foghatunk fel, zéró összegü játékot eredményezve. Ebben az esetben, ha az egyik fél nyer, a másik félnek definíció szerint veszítenie kell. A tiszta közös érdek foglalja magában a bizalomra épülö, teljes együttmüködési szituációt, melyet a teljesen azonos célok összessége jellemez s mely során mindenkinek ugyanaz a kifizetése.

A harmadik, alkujáték esetében a preferenciák negatív és pozitív korrelációja is megfigyelhetö, tehát egy olyan konfliktusszituáció áll elö, melyben jelen van a kölcsönös függőség is, illetve előfordulhat, hogy bár a célok hasonlóak, a kifizetések nem egyenlők. Valójában minden kereslet-kínálati, tehát cseremechanizmus egy kooperációs, vagy Schelling kifejezésével élve alkujátékként fogható fel, melyet alapvetően meghatároz a 
hiteles elköteleződés megléte, a kikényszeríthetőség informális vagy formális lehetősége. A felek által adott termék kapcsán felmerülő eladási és vételi szándék jelenti a közös célt, mely alapján minden gazdasági esemény alkujátékként definiálható.

$\mathrm{Az}$, hogy az adott interakció a piacon, a vállalaton vagy egy bizalmi alapú kapcsolat keretein belül folyik, attól függ, hogy az egyes alternatíváknak mekkora a tranzakciós, illetve adminisztratív költsége, melyet jelentősen befolyásol a bizalom mértéke. Úgy is fogalmazhatunk, hogy az a forma valósul meg, mely esetében - minden más tényezőt adottnak tekintve - a bizalmi szint a legmagasabb.

\section{A jogrendszer és a bizalom kapcsolata}

A továbbiakban a bizalom indirekt hatását a tranzakciós költségek és jogrendszer kapcsolatán keresztül mutatjuk be. Egyrészt széles körủ irodalom igazolja, hogy a bizalom csökkenti a tranzakciós költségeket (Fukuyama 1995b), másrészt szintén bizonyított, hogy a hatékonyabb jogrendszer kisebb tranzakciós költségeket eredményez (Coase 1960). A kérdés abban rejlik, hogy milyen a bizalom és jogrend közötti összefüggés, illetve a bizalom költségcsökkentő hatása érvényesül-e közvetetten is a jogrendszeren keresztül. Feltesszük, hogy a bizalom és a jogrendszer által generált költségek között negatív irányú kapcsolat van, így a magas bizalmi szint indirekten is hozzájárul a tranzakciós költségek csökkenéséhez.

A tranzakciók költségét alapvetően meghatározzák egyrészt a formális intézmények, mint a jogszabályi keret, a tulajdonjogok definiáltsága és a külső kikényszeríthetőség, másrészt az informális keret, mint a bizalom és a kultúra.

A jogrendszer hatékonysága nagymértékben befolyásolja a tranzakciós költségek nagyságát (Török 2007). A Coase-tétel alapján a jogrendszer a tranzakciós költségek csökkentésére törekszik, a tétel kiterjesztése pedig rámutat, hogy ezen költségek nem feltétlenül exogén tényezők (Cooter-Ulen 2005), így a jogrendszer hatékonyabbá tételével közvetlenül csökkenthetők a tranzakciós költségek. A jogrend egyszerüsítése viszont önmagában nem elégséges, mivel az a jogrendszerbe vetett bizalom növelése, a kooperatív légkör kialakítása nélkül nem lehet hatékony (Török 2007).

Az etikai normák egyre kisebb szintje hozzájárul a jogszabályok alóli kibúvási hajlandóság növekedéséhez, amit a jogrendszer szigorítása követ. Ez egyrészről bonyolultabb, átláthatatlanabb jogrendszerhez vezet, mely csökkenti a szerződések kikényszeríthetőségét (Ménard 2000), másrészről növeli a szabályozási költségeket. Mindez - ördögi kört kialakítva - az etikai normák továbbromlását eredményezi (Török 2007).

Arra a megállapításra juthatunk, hogy a bizalom költségcsökkentő tulajdonsága nemcsak közvetlen mechanizmusokon keresztül figyelhetö meg, tovagyürüzö, közvetett hatása számos esetben tetten érhető.

\section{Empirikus vizsgálat}

A szabályozási költségek részét képezi vállalati oldalról megközelítve az adminisztratív teher okozta költség, melynek bizalommal való kapcsolatát 25 európai ország esetében vizsgáljuk. Az elmélet szerint azt várjuk, hogy alacsony bizalmi szinthez bonyolult jogrendszer társul, mely magas adminisztratív terhet ró az adott gazdaságra. 
Az Európai Unió meghatározása szerint adminisztratív költség mindazon ráfordítás, amely azon információkkal jár, melyeket a vállalatok jogszabályi kényszer nélkül is összegyüjtenek. Azon információk összességét, amelyeket csak a jogszabályi kötelezettségek miatt szereznek meg, adminisztratív tehernek nevezzük (EC 2006).

\section{Az adminisztratív terhek okozta költségek és a bizalom szintje}

\begin{tabular}{|c|c|c|c|}
\hline & $\begin{array}{l}\text { Adminisztrációs } \\
\text { teher okozta költség } \\
\text { a GDP \%-ában } \\
(2003)\end{array}$ & $\begin{array}{l}\text { „A legtöbb emberben } \\
\text { meg lehet bízni." } \\
\text { (A megkérdezettek } \\
\text { \%-ában, 1999-ben }{ }^{a} \text { ) }\end{array}$ & $\begin{array}{l}\text { „Az ember soha nem } \\
\text { lehet elég óvatos.” } \\
(\text { A megkérdezettek } \\
\text { \%-ában, 1999-ben }{ }^{\text {a }} \text { ) }\end{array}$ \\
\hline Svédország & 1,5 & 63,7 & 32,4 \\
\hline Finnország & 1,5 & 56,8 & 41,1 \\
\hline Egyesült Királyság & 1,5 & 28,5 & 67,4 \\
\hline Dánia & 1,9 & 64,1 & 32,3 \\
\hline Írország & 2,4 & 35,2 & 63,1 \\
\hline Belgium & 2,8 & 29,4 & 66,3 \\
\hline Luxemburg & 2,8 & 24,9 & 70,9 \\
\hline Csehország & 3,3 & 23,4 & 74,6 \\
\hline Ny - Németország & 37 & 31,2 & 63,8 \\
\hline K - Németország & 3,1 & 40,7 & 54,8 \\
\hline Franciaország & 3,7 & 21,4 & 74,9 \\
\hline Hollandia & 3,7 & 59,4 & 39,9 \\
\hline Szlovénia & 4,1 & 21,2 & 76,4 \\
\hline Ausztria & 4,6 & 31,3 & 61,1 \\
\hline Spanyolország & 4,6 & 36,3 & 57,9 \\
\hline Olaszország & 4,6 & 31,8 & 65,6 \\
\hline Portugália & 4,6 & 9,8 & 87,9 \\
\hline Szlovákia & 4,6 & 15,2 & 81,8 \\
\hline Lengyelország & 5,0 & 18,3 & 78,6 \\
\hline Görögország & 6,8 & 20,5 & 65,8 \\
\hline Magyarország & 6,8 & 21,4 & 76,6 \\
\hline RE: Észtország & \multirow{5}{*}{6,8} & 21,7 & 73,2 \\
\hline RE: Litvánia & & 23,4 & 70,6 \\
\hline RE: Lettország & & 16,7 & 80,8 \\
\hline RE: Málta & & 20,4 & 78,2 \\
\hline RE: Ciprus & & na & na \\
\hline
\end{tabular}

Forrás: WVS (2008) és EC (2006) alapján

Megjegyzés: a Kivétel Finnország, amelyre vonatkozó adatok 2000-ből származnak. 
Az Európai Unió az adminisztratív terheket három fö csoportba osztva - közvetlenül a nemzetközi jogból származó, a nemzetközi jogszabály nemzeti szinten történő alkalmazásából eredő és a nemzeti jogszabályok okozta teher - az 1. táblázatban látható költségeket határozta meg 2003-ra vonatkozólag, a GDP arányában kifejezve (EC 2006).

Az 1. táblázat ezen felül tartalmazza a bizalom szintjét is, a megkérdezettek százalékos arányában. Finnország 2000-es adatát leszámítva, minden érték 1999-ből származik (WVS 2008), adathiány miatt Ciprus kivételével ${ }^{4}$.

\section{Az adminisztratív teher okozta költségek}

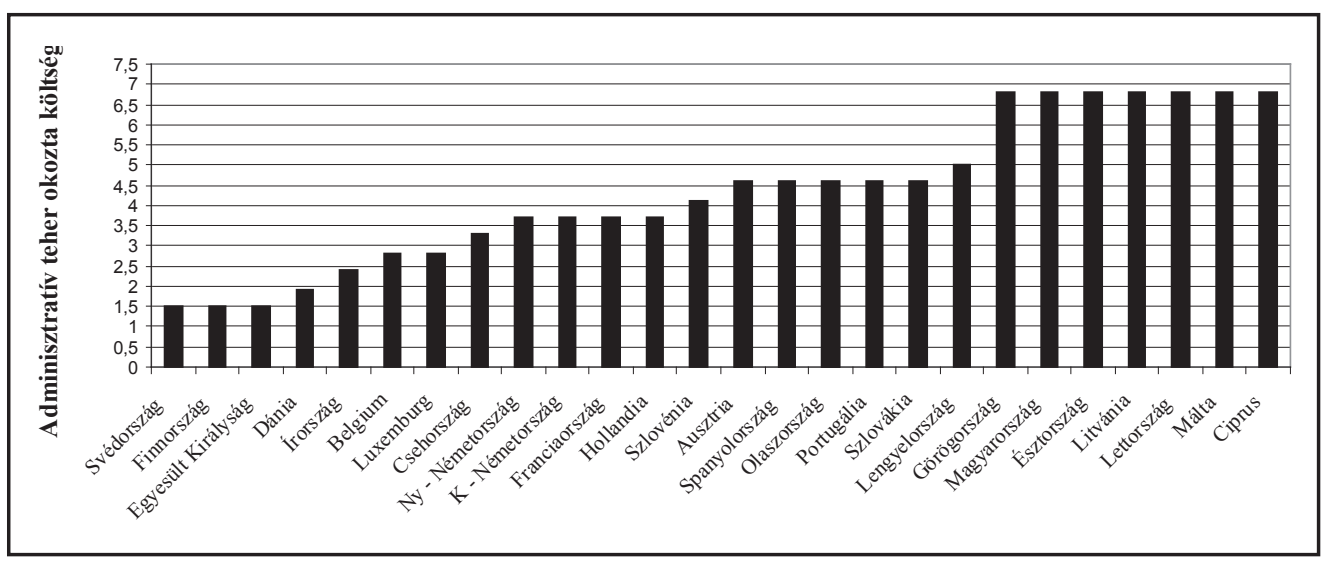

Forrás: EC (2006) alapján

2. ábra

\section{A bizalom szintje}

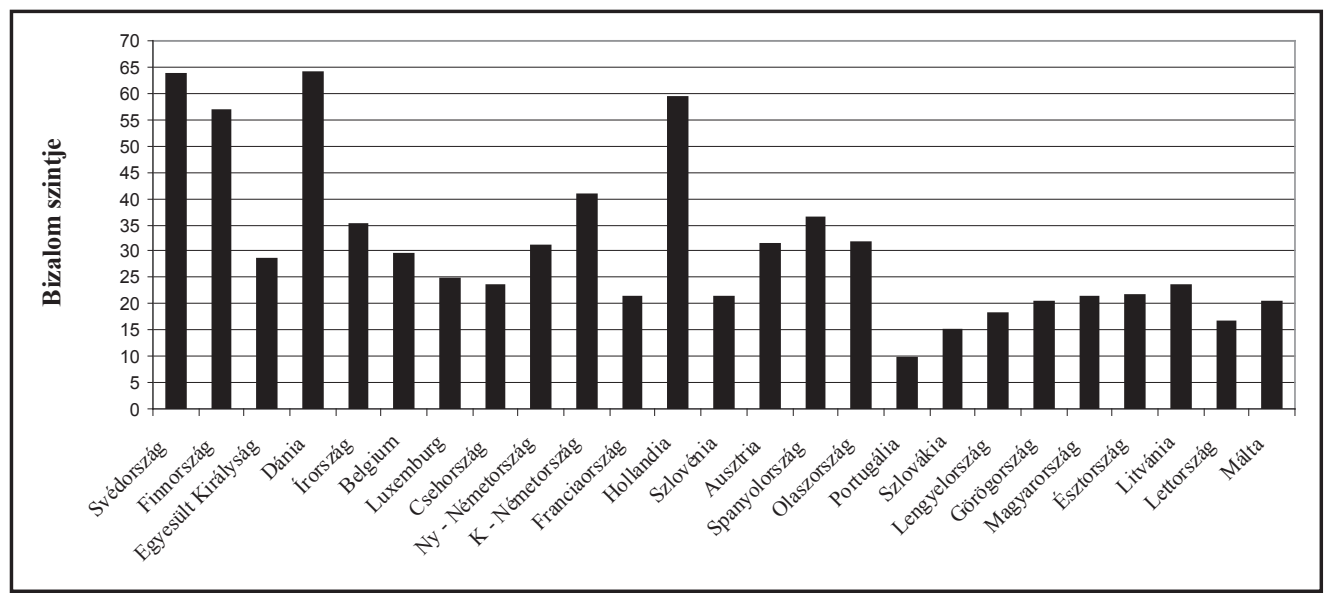

Forrás: WVS (2008) alapján

${ }^{4}$ Németország a 2.-es táblázatban még Nyugat-és Kelet-Németországként szerepel. 
Az EU25 országait az adminisztratív terhek okozta költségszintjük alapján sorba rendezve vizsgáljuk az elmélet és empíria egymáshoz való viszonyát. Az adatokat grafikusan az 1. és 2. ábra mutatja.

A 2. ábrán jól látható, hogy négy ország, Finnország, Svédország, Dánia és Hollandia esetében kiugró értéket figyelhetünk meg, 50\% feletti a bizalom szintje, az összes többi országra vonatkozóan ez az érték 50\% alatti, így azt a megállapítást tesszük, hogy ezekre bizalmatlanság a jellemző nagyobb mértékben.

A négy legalacsonyabb adminisztrációs teherből eredő költséggel rendelkező országból - Svédország, Finnország, Egyesült Királyság, Dánia - három egybeesik a magas bizalmi környezettel bíró országokkal, így igazolja az elmélet feltevéseit. Egyedül az Egyesült Királyság képez kivételt alacsony bizalmi szintjével (28\% véli úgy, hogy meg lehet bízni az emberekben, 1,5\%-os adminisztratív teher mellett).

Írországtól kezdve minden ország esetében a bizalmatlanság a nagyobb mértékủ. Itt is egy kivételt figyelhetünk meg, Hollandia tekintetében (3,7\% mellett az emberek 59,4\%-a szerint meg lehet bízni a legtöbb emberben).

A 3. ábra mutatja a bizalom és adminisztratív teher mértékét országonként, melyen jól látszik az elméletnek ellentmondó két ország - Hollandia és az Egyesült Királyság - esete.

\section{Adminisztratív teher okozta költségek és a bizalom kapcsolata}

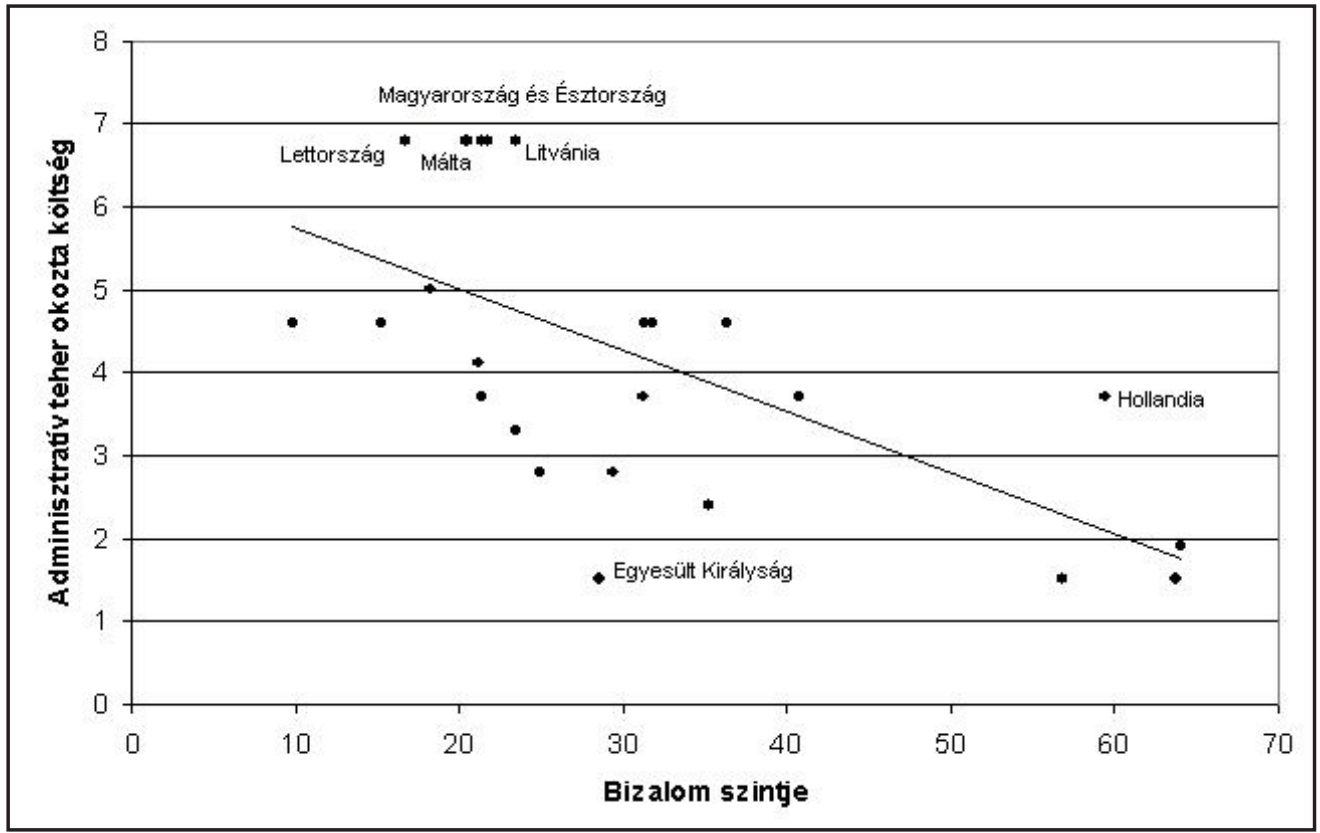

Forrás: WVS (2008) és EC (2006) alapján 
Magyarország, Málta és a balti államok kirívóan rosszul teljesítenek mindkét szempontból, hiszen a legmagasabb adminisztratív teher okozta költség párosul a legalacsonyabb bizalmi szintekkel. Ezen országok esetében jelentős, a trendvonaltól való eltérés figyelhető meg, ez azonban nem tekinthető kivételnek, a példájuk az elméletet igazolja. A fentebb említett országok kiemelése azért figyelemreméltó, mivel az esetükben az alacsony bizalmi szinthez várt adminisztratív teher mértékét a valóságban tapasztalt érték jelentősen meghaladja.

Összességében elmondható, hogy azokban az országokban a legalacsonyabb a jogi kötelezettségekből fakadó költség nagysága, ahol az emberek túlnyomó többsége bízik egymásban. A legmagasabb adminisztrációs teher okozta költségekkel rendelkezö országokban pedig a bizalmatlanság a jellemzö, így az elmélet alapján feltett hipotézissel megegyező eredményre jutottunk.

Két kivételt tapasztaltunk, az alacsony bizalmi szintü, ám így is alacsony költségszinttel bíró Egyesült Királyság, illetve a magas bizalmi szintű, mégis közepes költségszintü Hollandia esetét.

Az Egyesült Királyság tekintetében sejthető, hogy az alacsony bizalmi szintet a soknemzetiségű népesség és a nagyfokú nemzetiségi fluktuáció okozza. Az ebből fakadó kulturális különbözöségekből, illetve a közös múlt hiányából következhet nagymértékü bizalmatlanság (Keefer-Knack 2005). Az alacsony költségek hátterében a gazdaságösztönző politika, a jogrendszer átláthatósága, illetve a jogi kötelezettségek alacsonyabb volta állhat. Hollandia esetében ennek az ellenkezőjét figyelhetjük meg, az informális intézményi keret egyszerủbb, költséghatékonyabb formális intézmények kialakítását is lehetővé tenné. Az okok részletes felderítése további kutatás tárgya.

\section{Konklúziók}

Mind az elméleti áttekintés, mind a komparatív rész jól mutatja, hogy a bizalmon alapuló kapcsolatok fontos szerepet töltenek be a gazdaságban. A bizalom hiányának súlyos következményei lehetnek, mint például a végtelenül hosszú és komplikált szerződések, a kooperativitás teljes hiánya, az innovatív folyamatok lassulása, ügyek peres úton való rendezésének elburjánzása és a mindezekből fakadó gazdasági lassulás, hatékonyságvesztés (Tarnai 2003). Amennyiben a bizalom szintje alacsony, erőteljesebb kontrollra, a döntéshozatal és a struktúrák merevebb szabályozására van szükség.

Megfelelő feltételek mellett a hosszú távú, bizalmi kapcsolatok versenyelőnyt jelentenek ${ }^{5}$ (Wahl-Nowak 1999). A tranzakciós költségek nagysága és a bizalom szintje között szoros kapcsolat figyelhető meg. A gazdasági események játéktere - a piac, a vállalat vagy a bizalmi alapú kapcsolatok - attól függ, hogy az egyes alternatíváknak mekkora a tranzakciós, illetve adminisztratív költsége, melyet jelentősen befolyásol a bizalom mértéke. Az a forma valósul meg, amely esetében - minden más tényezőt adottnak tekintve - a bizalmi szint a legmagasabb.

Makroszinten nemcsak a bizalom direkt, tranzakciós költségeket csökkentő tulajdonságát figyelhetjük meg, hanem a jogrendszeren keresztüli tovagyürüző hatását is. Az etikai normák egyre kisebb szintje nagyobb fokú korrupt magatartást eredményez, amelyet a jogrendszer szigorítása követ, melynek eredményeképp bonyolultabb, átláthatatlanabb jogrendszer 
jön létre, csökkentve a szerződések kikényszeríthetöségét (Ménard 2000), és növelve a szabályozási költségeket, mely visszahatva az etikai normákra, azok továbbromlását eredményezi (Török 2007). Mindezt 25 európai ország empirikus vizsgálatán keresztül tanulmányoztuk, amely két kivételt leszámítva alátámasztotta alapfeltevésünket, miszerint alacsony bizalmi szinthez magas jogrendszer okozta költségek párosulnak. Nagy-Britannia és Hollandia esetének vizsgálata további kutatás tárgyát képezi.

A bizalom fontos versenyképességi és növekedési faktor, ezért a jövőben nagyobb figyelmet kell szentelnünk gazdasági hatásmechanizmusai megértésének.

\section{Irodalomjegyzék}

Al-Mutairi, M. S. - Hipel, K. W. - Kamel, M. S. (2008): Trust and cooperation frorn a fuzzy perspective. Mathematics and Computers in Simulation 76. szám, 430-446.

Artner Annamária (1995): Vállalati együttmüködés a mai világgazdaságban. Közgazdasági Szemle, XLII évf., 76. szám. 104--115.

Axelrod, R. (2006): The evolution of Cooperation. Basic Books, New York

Brenner, R. (1994): Labyrinths of Prosperity. Economic Follies - Democratic Remedies. The University of Michigan Press, Ann Arbor, 148.

Coase, R. H. (1960): The Problem of Social Cost. Journal of Law and Economics. 3. évf. 10. szám 1-44.

Coase, R. H. (2004): A vállalat, a piac és a jog. Nemzeti Tankönyvkiadó Rt., Budapest, 53-85., 37-215.

Cooter, R. - Ulen, T. (2005): Jog és közgazdaságtan. Közgazdasági Tankönyvek, Nemzeti Tankönyvkiadó, Budapest, 96-111.

Dahlman, C. J. (1979): The problem of Externality. Journal of Law and Economics, 22. évf. 1. szám 141-162.

Elster, J. (1997): A társadalom fogaskerekei. Oziris Kiadó, Budapest, 59-60., 67.

EC (2006): European Commission, Measuring administrative costs and reducing administrative burdens in the European Union. Commission Working Document, No. 2006(691).

Fukuyama, F. (1995a): Social Capital and the Global Economy. Foreign Affairs, 74. szám, 89-103.

Fukuyama, F. (1995b): Trust: The Social Virtues and the Creation of Prosperity. The Free Press, New York

Hámori Balázs (2003): Érzelemgazdaságtan - A közgazdasági elemzés kiterjesztése. Kossuth Kiadó, Budapest

Hodosi Anett (2008): Együttmüködés a gazdaságban. Tudományos Diákköri Dolgozat, Debreceni Egyetem Közgazdaságtudományi Kar, Debrecen, 16-35.

Keefer, P. - Knack, S. (2005): Social Capital, Social Norms and the New Institutional Economics. Megjelent: Ménard, C. J. - Shirley, M. (szerk.) (2005): Handbook of New Institutional Economics. Springer, US, 701-725.

Kovács Attila (2003): Kooperáció és versengés. Megjelent: Hunyadi György - Székely Mózes (szerk.) (2003): Gazdaságpszihológia, Osiris Kiadó, Budapest, 140-147.

Mayer, R. C. - Davis, J. H. (1999): The Effect of the Performance Appraisal System on Trust for Management: A Field Quasi-Experiment. Journal of Applied Psychology, 84. szám, 123-136.

Ménard, C. J. (2000): Institutions, Contracts and Organisations. Perspective from New Institutional Economics. Edward Elgar, Cheltenham, Egyesült Királyság - Northampton, MA, Egyesült Államok

Raiser M. - Rousso A. - Steves F. (2005): A bizalom mérése a rendszerváltás kapcsán: 26 átmeneti gazdaság vizsgálati eredményei. Megjelent: Kornai János - Rothstein B. - Rose-Ackerman S. (2005): Tisztesség és bizalom a posztszocialista átmenet fényében. A társadalmi bizalom megteremtése a posztszocialista átmenet időszakában. Nemzeti Tankönyvkiadó Rt., Budapest, 73-87.

Schelling, T. C. (1958): Prospectus for a Reorientation of Game Theory. The Rand Corporation, California, USA.

Schelling, T. C. (1963): The Strategy of Conflict. Oxford University Press, New York

Tarnai Márta (2003): A bizalom szerepe a gazdasági kapcsolatokban. Megjelent: Hunyadi György - Székely Mózes (szerk.) (2003): Gazdaságpszichológia. Osiris Kiadó, Budapest, 676-715.

Török Ádám (2007): A versenyképesség egyes jogi és szabályozási feltételei Magyarországon. Közgazdasági Szemle, LIV. évf. 12. szám 1066-1084.

Wahl, L. M. - Nowak, M. A. (1999): The continuous prisoner's dilemma: II. Linear reactive strategies with noise. Journal of Theoretical Biology, 200. évf. 3. szám 323-338. 
Woodruff, C. (2005): Az üzleti partnerek iránti bizalom megteremtése: a biróságok, hálózatok és kapcsolatok szerepe. Megjelent: Kornai János - Rothsten, B. - Rose-Ackerman, S. (szerk.) (2005): Tisztesség és bizalom a posztszocialista átmenet fényében. A társadalmi bizalom megteremtése a posztszocialista átmenet időszakában. Nemzeti Tankönyvkiadó, Budapest, 128-142.

WVS (2008): World Values Survey, Most people can be trusted. 9062000 . - Values Surveys A165. 